\title{
Collaborative Governance in Handling Traffic Problems in the City of Surabaya
}

\author{
${ }^{1 \text { st Muhammad Farid Ma'ruf }}{ }^{1},{ }^{2 n d}$ Deby Febriyan Eprillianto ${ }^{2}$ \\ ${ }^{3 \mathrm{rd}}$ Suci Megawati ${ }^{3}$ \\ \{muhammadfarid@unesa.ac.id ${ }^{1}$, debyeprilianto@unesa.ac.id ${ }^{2}$, \\ sucimegawati@unesa.ac.id ${ }^{3}$ \} \\ Department of Public Administration Universitas Negeri Surabaya, $082232349484^{1}$, Departement \\ of Public Administration Universitas Negeri Surabaya 085725925055² , Departement of Public \\ Administration Universitas Negeri Surabaya \\ 087760314434
}

\begin{abstract}
Surabaya has traffic problems that call for very complex handling quickly and correctly. Traffic police as main authority traffic have limited in reaching the entire area throughout Surabaya. Support the other hand (private sector and society) to be inseparable in handling traffic problems in practice collaborative governance. Research carried out with the methods descriptive with a qualitative approach through a focus of study to the collaborative governance between Police Resort City of Surabaya, Radio Suara Surabaya, and society. Study analysis used 5 indicators of the process of collaborative governance such as face to face dialogue, trust-building, commitment to the process, shared understanding, and intermediate outcomes that were implemented positively. This collaboration is carried out in handling traffic in Surabaya, in the form that stakeholders are involved in analyzing community traffic information so that it can carry traffic in the city of Surabaya. An important conclusion in this study is the contribution of the private sector and society to the very important problem of handling traffic in the city of Surabaya. However, recommendations for several weaknesses in practice collaborative governance is still needed.
\end{abstract}

Keywords: Collaborative, Governance, Response and Contribution.

\section{Introduction}

Government management is required to always adjust to what is needed in the environment as a form of response and effort to interact and adjust the development of its community. In addition, government organizers must be able to quickly adapt to global change so as to cover the overall interests of government stakeholders in democracy. Realize this function, the government needs to accommodate all the demands on the community environment with a method of cooperation between stakeholders that is mutually sustainable. The term cooperation between stakeholders in carrying out public activities involves several elements that are inter sustainable between the Government, Private and Community which in the study of the science of Public Administration is known as the concept of Collaborative 
Governance and Intergovernmental. The transformation of government thinking into governance in the approach of state/public administration builds the use of government as a public institution directly or indirectly will engage with non-governmental stakeholders (private) who receive the impact of governance in the form of formal decision-making. The implementation of this understanding leads to the need for a shared awareness of the importance of cooperation, partnership, collaboration or other commensurate concepts in supporting the task of organizing government primarily providing good public services. The end is to be able to create or implement a policy based on the demands that exist in the internal context of the government or the external environment of the government, in this case the public (community). Discussions of governance management in management studies and public policy found the relevance of the impact of cooperation (collaboration, partnership or other concepts) in the administration resulted in a policy that could be optimized in the form of a plan. The study and findings of Innes and Booher, Healy, and Gunton and Day suggest that cooperation planning has been successfully carried out in several countries in addressing problems such as the environment, security, traffic and in managing water that includes many stakeholders and cross-regions (Sufianty, 2014) as quoted (Irawan, 2017). Lately, the development approach in Indonesia has begun to implement collaboration practices, partnership in the implementation of development, especially in the provision of public services. This is certainly an exit option for common developing countries such as poverty, health, education and even transportation. The common problems of transportation in developing countries are very complex ranging from the facilities, infrastructure and traffic habits of the community that have not been good.

One of the traffic problems is the poor level of traffic congestion in major cities including Surabaya. Based on rillis survey results from the Asian Development Bank (ADB) as reported in (finance.detik.com), in September 2019 Surabaya was among the 45 countries incorporated in the Asian Development Bank (ADB) of the 278 cities studied. They release placed Surabaya in 24 major cities with a population of five million with an average congestion o f 1.51 .

Development Outlook in the September 2019 issue. Based on this initial phenomenon, this study explored and descriptively presented the Collaborative Governance process that was established between the police resort city of surabaya, Radio Suara Surabaya and Surabaya citizen and surrounding communities using the cycle instruments and phasing out the collaborative governance process that was formulated delivered [1].

Several studies examine this theme, among others, research conducted by Rahwayu and Dewi (2015) with the result, interactors communicate with each other regularly in preparing and implementing ethical culture activities in traffic. Besides, the collaboration also involves non-government / private elements, namely PT Astra Honda Motor (AHM) by utilizing corporate social responsibility to integrate ethical education into the school curriculum of learning. Also, the implementation of the School of Cross Ethics Education Model which is a collaboration between the Education Department of Yogyakarta City, the school, and the Police is a real example of collaborative governance. Another research was conducted by Hafifa who researched Collaborative Governance in the Surakarta City Road Traffic and Transportation Forum. This research shows that the implementation has not involved all actors in it, face to face dialogue and direct communication are still lacking. Collaboration barriers are related to the network structure that tends to form a hierarchy, the absence of freedom to collaborate, inadequate allocation of financial resources, the absence of quality control, and the presence of structural egos. Furthermore, research conducted by Tilano and Suwitri , the results showed collaborative governance in the implementation of traffic safety and 
road transport in Semarang seen first conditions, institutional design, and collaborative process has been running well, but not an optimal implementation of facilitative leadership [21]. The driving factor which affects the collaboration that is networked structure, commitment to a common purpose, distributive accountability/responsibility, and information sharing, while the only factor inhibiting access to the resource. The recommendations given are implementing more maximal facilitative leadership by leveraging the existing Traffic and Road (LLAJ) Forum and held a contract employee recruitment and planning more effective and efficient. From some of these studies, it is considered very important to conduct an indepth study of collaborative governance in handling traffic problems in the city of Surabaya.

\section{Methodology}

Writing in research is done using descriptive methods with a qualitative approach. A qualitative approach is an approach using descriptive data in the form of written data or words directly from the person or perpetrator observed. This qualitative method is often referred to as a naturalistic research method because in its research conducted in natural conditions The purpose of descriptive research selection allows the author to collect data randomly, make descriptive, interpret existing problems factually and in detail according to the data obtained on Radio Suara Surabaya and Police Resort City of Surabaya from Traffic Unit and Surabaya Radio Listeners based on collaborative governance process [20].

The source of this research data is obtained from the key information in this study, namely from a). Radio Suara Surabaya public relations, b). Head of Surabaya Police Traffic Unit, c). Radio Suara Surabaya Listeners with a total of 7 people selected randomly based on Radio Suara surabaya listener data. Meanwhile, secondary data sources are obtained from the process of collecting reporting data and traffic that can be obtained from the Traffic Center Management (MTC) of the Police Resort City (Polrestabes) of Surabaya. In addition, observation is carried out by listening intensely to Radio Suara Surabaya broadcast in receiving and conveying traffic information. After the data is collected, Once the data is collected, analyze the data through interactive methods (Miles, Huberman \& Saldana, 2014).

The analysis was conducted in a 5-stage study of the Collaborative Governance (Ansell \& Gash, 2007)process which included: a). face-to-face dialogue, b). Trust building, c).commitment to process, d). understand each other and, e). long-term orientation. Thus it can be known various achievements and problems occur in the cooperation process that has been carried out. Through collaborative governance approach this research produces a model of strengthening cooperation that is appropriate for the service and handling of traffic problems in Surabaya.

\section{Finding and Discussion}

\subsection{Collaborative Governance : an important approach in the study of Public Administration}

The strengthening of the governance approach in administrative science, its practical implementation can be seen by the increasing number of efforts to implement new governance with a collaborative governance model. The concept is in line with the meaning of governance where there is an effort to unite and involve public and private stakeholders in a collective 
forum with public institutions to be involved in consensus-oriented decision making. Ansell and Gash study seeks to define collaborative governance as follows: "A governing arrangement where one ormore public agencies directly engage non-state stakeholders in a collective decision-making process that is formal, consensus-oriented, and deliberative and that aims to make or implement public policy or manage public programs or assets". (Ansell \& Gash, 2007)"Collaborative Governance in Theory and Practice". Journal of Public Administration Research and Theory, 18 (4), p 544 [1].

What was said (Ansell and Gash, 2008) can be interpreted that collaboration is an effort to regulate two or more institutions that take care of public affairs, either directly or indirectly. Such institutions have equal importance in regulating non-state affairs. Each party must have a formal attachment and responsibility and have a strong commitment to the things that are agreed. There is a division of duties, where tasks are entrusted fully to each party while still coordinating in planning and implementing programs related to the public interest.

Collaboration according to Haryono (Haryono, 2012) as cited (Irawan, 2017) is all actions that include cooperation activities, interconnected and mutual understanding of the parties involved either individually, institutions or parties directly or not involved with obtaining consequences and benefits. Collaboration in the perspective of party involvement in detail Thomson and Perry (Thomson, 2006) as cited (Fairuza, 2017) reveals that collaboration as an activity where stakeholders who have autonomous power move and relate through the negotiation process either formally or not, by jointly creating a rule and structure to regulate relationships and ways of acting or to make a decision on an issue that brings them into the imperative of togetherness. In addition, in the role study, Slesky and Parker in Dwiyanto provide rationality of the involvement of a partner between the government and the private sector by dividing it into three platforms [5]. The first platform is reliance on resources, social issues, and sector groupings. These limitations form the basis for agencies in making decisions to collaboratively solve and address problems faced by the public. The second platform that can support a partnership is the concern of stakeholders to Problems concerning social interests that are discussed together. Problems such as poverty, environmental damage, and social conflict, which are perceived to interfere with the common interest, will encourage stakeholders to collaborate on resolving these Problems. The third platform, referred to as the social sector platform, explains that the obscurity of the characteristics of government institutions, civil society, and corporations makes it unclear the difference between the three.

Furthermore, Dwiyanto emphasized that this happened because other agencies played what had previously been their third role [5]. When one of the functions of the government is contracted in providing public services to the private sector or civil society then the differences in roles between the three will become very blurred. Furthermore, in collaborative service management there is no need for hierarchies, but rather functional relationships based on networking. The mechanism of action developed in collaborative management is a functional mechanism of action, in which each party carries out activities based on the functions it has in solving public problems in accordance with the mutually agreed division of work.

Practice, collaboration in the implementation of traffic problems is certainly not necessarily going well and smoothly. There are many barriers related to compliance level, stakeholder role and consistency. The conclusion of the study for example found that the level of compliance with both (enforcement of both) played a role in imposing compliance on both of them that protect citizens or simply increase the legal certainty that exists in the implementation of transportation policies in Makassar city [14]. Traffic and Road Transport Forum in terms of inter-organizational network which of course also affects 
enforcement of both on the implementation of transportation policy. one of the programs encouraged from the forum, namely Kamseltibcar Lantas (Security, Order, Safety, and Smooth Traffic), in its implementation does not involve all parties.

Research on collaboration governance was conducted by Dimas Luqito Chusuma (Arrozaaq, 2016) Denny Irawan (Irawan, 2017) Mia Fairuza (Fairuza, 2017) Iqtikaful Furqoni[2]. (Furqoni et al, 2019)has not generally demonstrated maximum collaborative governance,

some components and processes that have not gone well such as leadership, stakeholder commitment, trust, communication, collaboration environment, etc. In this paper focus on the collaborative governance process.

According to (Emerson et al., 2011) introducing collaborative governance regime (CGR), this theory describes in detail how the collaboration process is dynamic and cyclical, by producing temporary actions and impacts, before leading to major impacts, as well as adaptation to temporary impacts. The collaboration process requires components and stages in the form of: (1) Collaboration dynamics, (2). Collaborative actions, and (3) [7]. Temporary impact and temporary adaptation of the collaboration process.

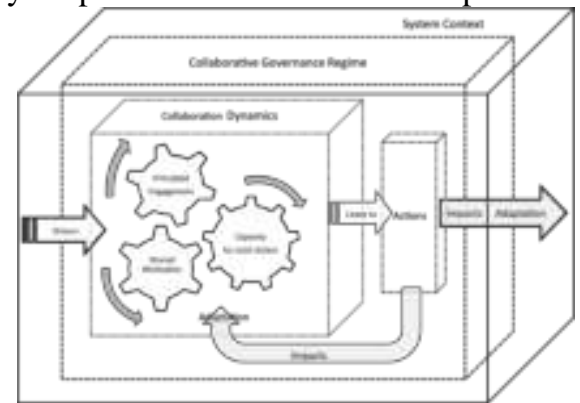

Figure 1. The Collaborative Government Theory according to Emerson, Nabatchi, \& Balogh

\subsection{Description of collaborative governance process in handling traffic problems in Surabaya.}

An important focus in the study of collaborative governance handling traffic problems in Surabaya is to look at the collaborative governance process based on the theory put forward by (Ansell \& Gash, 2007) Furthermore, the collaboration process is described as a cycle rather than a gradual process. As a sub-component cycle in the collaboration process affects each other.

In relation to the collaboration process, Ansell and Gash's view provides several indicators Collaborative governance can run properly if it has run 5 (five) interconnected stages namely: a). face-to-face dialogue,b). building trust, c).commitment to process, d). understanding each other, and e). Long-term goals. This research focuses the results of the study on the process in the concept of collaborative governance towards the practice of handling traffic problems in Surabaya city [1]. The description of the results of the study in the collaboration process can be described below:

a. Face to face dialogue;

The meaning of face-to-face dialogue is the process or the initial stage before the agreement is reached is the need for dialogue between the parties who plan and agree in cooperation. Ansel and Gash as quoted in (Rahmawati, 2016) provide an understanding that as a consensus-oriented process, face-to-face dialogue or can be called direct dialogue is 
required by stakeholders to identify opportunities for mutual benefit. Important dialogue is conducted to equate perceptions between the parties involved in collaboration to build design and mutual agreement and minimize misunderstandings between the parties involved in the collaboration. The results showed that this stage was carried out by Radio Suara Surabaya appointed the public relations department and in the Police resort city of surabaya appointed a Traffic Unit in the field of coaching operations. The meeting between representatives of Radio Surabaya (SS) Public Relations and Police Deapartment, especially Police Resort City (Polrestabes) of Surabaya began with the same concerns regarding traffic problems in surabaya city. The condition strengthens the determination of the two agencies to find a solution based on the potential possessed by radio surabaya which has a large audience combined with the capacity and authority of Police resort city of surabaya (polrestabes) in regulating traffic affairs.

In addition, the observations made by researchers towards the dialogue stage in the collaborative governance process are carried out very well. This conclusion can be seen from the communication pattern between the Radio suara Surabaya (SS) crew and the Traffic Management Center (NTMC) by Police Department has monitoring officer that is very well established. Research observations conducted by listening to Radio SS, whenever there are knots of congestion in Surabaya directly can be communicated by the public on the radio and responded by the Traffic Unit (Satlantas) Police Resort City Of Surabaya very quickly. The results are in line with previous collaborative studies conducted where in realizing cooperation or collaboration, face-to-face dialogue or two-way communication (reciprocity) between agencies or institutions with stakeholders in the context of meeting and making a consensus agreed is a collective decision and a shared responsibility[4]. Meanwhile, for (Ansell \& Gash, 2007:571) mutual understanding is the basis for the formation of an important consensus to be realized to reduce risks in collaboration / collaboration practices[1].

\section{b. Trust Building}

Collaboration requires a trust between one party and the other, because mutual trust between the parties will facilitate the course of collaboration. The stages of the Trust Building process as required by Ansell and Gash have been built between stakeholders namely Radio Suara Surabaya and The Traffic Unit (Satlantas) of The Police Resort City of Surabaya and the community with the aim of making stakeholders trust each other[1].

The data gives an idea that Radio Suara Surabaya is still a radio that is trusted by the public in obtaining and conveying various public information. The data was also supported by the recognition of most listeners from one of the pens such as Mr. Sujiono who stated that:

"Radio Suara Surabaya is a radio channel that I always choose and listen to when traveling by car. For me, Suara Surabaya provides information especially about traffic that can help me in choosing lanes to avoid congestion. I also often send information to Suara surabaya through telephone directly related to the traffic conditions that fit the route I passed".

Another listener, Mr. Bambang Sigit also expressed a similar view that :

" When talking about trust, I can get through the rapid response and validity of the information conveyed by Radio Suara Surabaya as well as concrete evidence of the many problems that can be resolved ranging from the loss of motor vehicles, people and in terms of addressing the density of traffic that happens every day in Surabaya. It was all carried out with excellent coordination and neat and speed of handling carried out by the Traffic Unit of 


\section{The Police Resort City of Surabaya".}

Furthermore, the Research and Survey Section of Radio Suara Surabaya also stated that many people convey various information via telephone with the number of 13,859 callers every month, with $80 \%$ of callers conveying information related to the main traffic conditions in Surabaya and surrounding cities. The community thinks that conveying complaints experienced to Radio Suara Surabaya is faster than it will be by submitting a complaint directly to the Traffic Unit of The Police Resort City of Surabaya. Radio Suara Surabaya listeners are also facilitated through social media accounts as a platform to accommodate complaints or community complaints related to Traffic in Surabaya that can follow current trends or times, so that all circles can access and actively participate to submit their complaints to Traffic in Surabaya to be quickly resolved.

Meanwhile, in an effort to build trust with the public, Radio SS provides information media facilities through twitter, facebook, instagram. Evidence of strong public confidence in the validity of Radio SS information based on the author's observations when listening to the live broadcast of Radio Suara Surabaya.

Collaborative governance at the trust building stage between Radio Suara Surabaya and The police resort city of surabaya and the community in dealing with traffic problems in Surabaya. The condition in the De Seve Study as cited by Sudarmo ) has led to the establishment of a trust among the participants. This is detected from interviews with listeners, data findings and observations of researchers, where each party is involved by providing accurate information references [18].

\section{c. Commitment to Process}

Commitment to collaboration is an important variable in a collaboration that is executed. The commitment of each stakeholder in carrying out the collaboration process is important so that the agreement in a collaboration can be executed properly. Radio Suara Surabaya has a high commitment in collaboration on handling traffic problems with the community and Police Department. The commitment is in line with the function of mass communication media such as: 1). Information, 2). Socialization, 3). Motivation, 4). Debates and discussions, 5). Education, 6). Introducing culture and 7). Entertainment. (Effendy, 2011)

Based on Law of Republic Indonesia Number 2 of 2002 concerning the State Police

of the Republic of Indonesia, Article 13 states that the Police of the Republic of Indonesia in general has a fundamental duty: a. maintaining security and public order; $b$. enforce the law; and c. provide protection, and service to the community. In the context of providing protection and service to the community, one of them is used in a special unit namely the Traffic Task Force (Satlantas). Satlantas specifically and functionally have duties and responsibilities in the traffic settings set out in article 200 (Law Of The Republic Of Indonesia Number 22 Year

2009 Concerning Traffic And Road Transport ) there is a provision that: " The National Police of the Republic of Indonesia is responsible for the implementation of activities in realizing and maintaining Traffic Safety and Road Transport". The legal basis is a foothold for the police to exercise authority in the management and management of traffic. The implementation of the authority synergizes with other stakeholders such as the ministry of transportation, local government and road users.

One strong evidence of the commitment of both sides can be found from observation through efforts to respond to public complaints related to traffic in Surabaya. Second, Radio SS also provides social media accounts on Twitter, Facebook, Instagram as a medium to 
provide information interactively to both the public and the authorities.

In addition to the strong commitment of Radio Suara Surabaya and the Traffic Unit of the Surabaya City Police, a strong commitment from the community is also needed because the community is the provider of information on existing problems. The results of the interview related to the collaborative governance process at the commitment to the process stage between Radio Suara Surabaya and Police Resort City of Surabaya related to traffic in Surabaya City, has gone well. Each of the parties involved in the collaborative governance process jointly builds and maintains mutual commitments that have been implemented since the beginning of the collaboration. The public or information givers on the problems they face by providing information that is truthful and in accordance with what is happening.

An important finding of the commitment stage in this process is that the involvement of government stakeholders other than the police is less visible. This is because of the agreement of collaboration between SS Radio and Police resort city of surabaya without seeing the role of other institutions /ministries in the government. When looking at the regulation of Law 22 of 2009 on traffic and highways, then other stakeholders who are interested in traffic can be mapped among others the Ministry of Transportation, Local Government, Transportation Companies (private) and community road users. This is clearly stated in article 256 which states: "The public has the right to participate in the implementation of Traffic and Road Transport". Similarly, other government organizers are very clear about the division of authority in traffic management. Novita's study mentions that, the problem is related to the process of understanding the importance of collaboration, because the collaborative process takes a long time and not a moment[15].

\section{d. Shared understanding}

At some point in the collaboration process, stakeholders must develop a common understanding of what they can achieve collectively so that the collaborative journey does not take decisions that harm one of the stakeholders. The Share understanding stage of the collaboration process is that the stakeholders involved must share an understanding of what they can achieve through collaboration. These various understandings can be described as shared missions, common goals, common objectivity, shared visions, common ideologies, etc. The form of sharing understanding can have implications for mutual agreement to define and interpret a problem while managing solutions together. In this context, Innes and Booher (2003) as quoted see that the consensus process or consensus reached by communicative action must be in a condition where each actor is able to realize the interdependence of interest, a position of interdependence depending on the interests of the actor[13].

The process of understanding each other in collaboration by all stakeholders that the traffic problem management activities in Surabaya are based on a high awareness of the parties concerned to resolve each other's traffic problems in Surabaya. This is in accordance with the statement from Mr. Adi as a Public Relation's Radio Suara Surabaya:" "the original purpose we stood for was to be in the middle of the community, to help the community in solving a problem, in another sense we exist to benefit the community, especially in Surabaya, we see in conveying complaints the community is often feared with rigid and convoluted services, therefore Suara Surabaya is present to answer that, so that what is a community problem can be solved quickly, especially on traffic problems". This statement is supported by a statement from AKP. Su'ud as Head of the Operation Traffic Unit of Police Resort City of Surabaya: "serving the community is our main task, therefore community problems are our priority, so here we will not be selective in helping the community, in receiving reports from the public and 
also the handling of the report itself which is certainly on traffic problems in Surabaya Because we are aware that traffic congestion will hamper the activities of the community itself, so if we are not the one solving the problem, then who will, on the other hand we also realize that it is our main task as traffic police". The implementation of a shared understanding stage between Radio Suara Surabaya, Police Traffic Unit Police resort city of surabaya and the public can be seen from efforts to give time to Surabaya Police to convey its policy through radio broadcasts on air. The goal is for traffic regulations to be socialized and understood by the public supported by Radio Suara Surabaya.

Practical conclusions on the collaborative governance process at the shared understanding stage between Radio Suara Surabaya and Police Resort City of Surabaya regarding traffic problems in Surabaya are established based on the agreement of authority and the division of duties of each party. But the finding in the collaboration process at this stage is that this collaboration is not included in the written agreement either in the form of a memorandum of understanding $(\mathrm{MoU})$ between the two parties that have cooperated. This is not something that should be in the collaboration process, but it is feared that there is a misunderstanding between the two due to the absence of a binding basis or written agreement.

\section{e. Intermediate Outcome}

Intermediate Outcome is the result obtained after the collaboration process, which will be implemented in the long term will reach the final outcome or final result. The determination of Intermediate Outcome for this collaboration can be traced from the sources of Police Resort City of Surabaya and Radio Surabaya. Radio Suara Surabaya which thinks that the handling of public complaints in Surabaya, especially in Traffic, is still not going well, so a collaboration process is needed that can facilitate the delivery of complaints from the public, namely through Private Radio, namely Radio Suara Surabaya. Furthermore, Radio Surabaya sources argue that it will take time to achieve this goal, so it must be ensured that the community will be able to make it easier to submit its complaints mainly on traffic problems in Surabaya.

As for Police Resort City of Surabaya, collaboration in the handling of traffic problems is a step to improve the quality of good service to the community. This is as stated by the head of operation section of the Traffic Unit of Police Resort City of Surabaya, Mr. AKP. Su'ud as follows: "The long-term results that we want to achieve from this collaboration are only one, which is to help the community. Because our most important task is to serve the community so that we with all the limitations of thought and personnel always strive to facilitate the service as requested by the community, especially on traffic problems"

The findings of intermediate outcome in the collaboration process conclude that this collaboration process can continue, although it is not tied to the written agreement between Radio SS and Police resort city of surabaya. In this phase, research (Asropin \& Ma'ruf, 2020) provides reinforcement that this collaboration activity aims to help and facilitate the community to convey complaints faced primarily on traffic problems. So that both sides as the main node of cooperation implementation can be considered successful in carrying out cooperation well. But the fact can be negative in terms of the ideal concept of collaboration, where the clarity of a written agreement in the future (term long) becomes an important basis for the collaborating parties[3]. 


\section{Conclusion}

The collaborative governance practices and processes in the handling of traffic in Surabaya has aplicated by Radio Suara Surabaya and The Police Traffic Unit of Resort Besar Kota Surabaya run in accordance with the expectations and objectives of the cooperating parties. Each party involved is able to carry out its own role in accordance with its capacity and responsibilities. Then the results of the analysis in the context of the study stage of the collaborative governance process based on 5 (five) indicators according to (Ansell \& Gash, 2007) the conclusions that can be described are as follows [1]:

At the face to face dialogue stage has been carried out well in the process of conducting collaborative governance in an effort to respond to public complaints related to traffic in Surabaya by the stakeholders involved, where stakeholders have held many meetings both formally and informally, so as to gain a common understanding related to the duties, principles and functions of each stakeholder and achieve a common goal, so that the problems that are addressed by the community related to traffic in Surabaya city can be resolved little by little quickly.

Second, the Trust Building. This indicator of collaborative governance process is demonstrated by the rapid and responsive response and good of each stakeholder involved, especially the Police Traffic Unit of Policy Resort City of Surabaya, and on Radio Suara Surabaya and the community is shown by providing valid and accountable information, so that there can be good trust between stakeholder involved, so that the collaborative governance process in response to community complaints related to traffic in Surabaya can run well.

Third, commitment to the process. This indicator of collaborative governance process is demonstrated by the validity of the information provided by Radio Suara Surabaya, both to the community and the Police Traffic Unit of Policy Resort City of Surabaya has been verified and in accordance with what is in the field, further the commitment given by the Traffic Unit of The Police Traffic Unit of Policy Resort City of Surabaya is with responsive responsiveness and good response to complaints submitted by the public through Radio Suara Surabaya, so that the collaborative governance process can be implemented properly and smoothly until it gained the trust of the community.

Fourth, shared understanding. This indicator of collaborative governance process is demonstrated by knowing each other's duties, points and functions as well as the same objectives of each stakeholders involved. With many meetings held both formally and semiformally, the authors found there had not been a written and binding agreement between stakeholders involved in this shared understanding indicator. The creation of a written and binding agreement or MOU is very important to avoid misunderstandings one day, between stakeholders in the running of this collaborative governance process.

Fifth, intermediate outcomes. This indicator of collaborative governance process is demonstrated by the achievement of the objectives of this collaborative governance, namely, the resolution of community complaints related to traffic problems in Surabaya, as well as the achievement of public trust in each agency in stakeholders involved in this collaborative governance. So that people do not have to worry anymore to submit complaints and in carrying out travel or activities in Surabaya.

The important contribution of collaborative governance research study and analysis in traffic handling in Surabaya is summarized in the following recommendations:

1. The collaborative governance process is supported by a written and bounded agreement between stakeholders and each other involved in the collaboration. The goal is 
synergy and division of tasks.

2. Consider the involvement of organizers and related stakeholders such as the Ministry of Transportation, Local Government, Transportation Company (private) and community road users in the process of cooperation on handling traffic problems.

3. Despite the weaknesses and constraints that occur, Collaborative governance related to traffic that has been stepped up by SS radio and Surabaya Police is expected to be a role model for other areas or districs.

\section{References}

[1] Ansell, C., \& Gash, A. (2007). Collaborative governance in theory and practice. Journal of Public Administration Research and Theory, 18(4), 543-571. https://doi.org/10.1093/jopart/mum032

[2] Arrozaaq, D. L. C. (2016). Collaborative Governance ( Studi Tentang Kolaborasi Antar Stakeholders Dalam Pengembangan Kawasan Minapolita n di Kabupaten Sdioarjo [Universitas Airlangga]. In PhD Thesis. Universitas Airlangga. http://repository.unair.ac.id/67685

[3] Asropin, \& Ma'ruf, M. F. (2020). Collaborative Governance Dalam Upaya Merespon Pengaduan Masyarakat Terkait Lalu Lintas ( Studi Pada Radio Suara Surabaya Dan Kepolisian Resort Kota Besar Surabaya). Publika, 2(8).

[4] Astari, M. M., Mahsyar, A., \& Parawangi, A. (2019). Kolaborasi Penertiban Moda Transportasi Di Kota Makassar ( Studi Kasus Kendaraan Becak Motor ). JPPM: Journal of Public Policy and Management, $1(1)$.

[5] Dwiyanto. (2012). Manajemen Pelayanan Publik: Peduli Inklusif dan Kolaboratif. Universitas Gadjah Mada Press.

[6] Effendy, O. U. (2011). Ilmu Komunikasi: Teori dan Prakteknya. Bandung Remaja Rosdakarya.

[7] Emerson, K., Nabatchi, T., \& Balogh, S. (2011). An Integrative Framework for Collaborative Governance. Journal of Public Administration Research and Theory, June 2009. https://doi.org/10.1093/jopart/mur011

[8] Fairuza, M. (2017). Kolaborasi antar Stakeholder dalam Pembangunan Inklusif pada Sektor Pariwisata ( Studi Kasus Wisata Pulau Merah di Kabupaten Banyuwangi ). Kebijakan Dan Manajemen Publik, 5(3), 1-13.

[9] Furqoni Iqtikaful, Slamet Rosyadi, A. I. (2019). Collaborative Governancein Corporate Social Responsibility Forum in Banyumas Regency. Jurnal Bina Praja, 209-217. https://doi.org/10.21787/jbp.11.2019.2019.209-217

[10] Hafifa, R. (2016). Collaborative Governance dalam Forum Lalu Lintas dan Angkutan Jalan Kota Surakarta. Dogital Library of Universitas Sebelas Maret Surakarta

[11] Haryono, N. (2012). Jejaring Untuk Membangun Kolaborasi Sektor Publik. Jurnal Jejaring Administrasi Publik, 4(1). journal.unair.ac.id

[12] Irawan, D. (2017). Collaborative Governance (Studi Deskriptif Proses Pemerintahan Kolaboratif Dalam Pengendalian Pencemaran Udara di Kota Surabaya ). IRPerpustakaan Universitas Airlangga, 5, 1-12.

[13] Kurniasih, D., Setyoko, P. I., \& Imron, M. (2017). Collaborative governance. Sosiohumaniora, 19(1), 1-7.

[14] Mediansyah, A. R. (2017). Jurnal Analisis dan Kebijakan Publik. Jurnal Analisis Dan Kebijakan Publik, 3(1), 14-22. 
[15] Novita, A. A. (2018). Collaborative Governance dan Pengelolaan Lingkungan Hidup di Kawasan Pertambangan. Jurnal Ilmiah Administrasi Publik, 4(1), 27-35. https://doi.org/10.21776/ub.jiap.2019.004.01.4

[16] Rahayu, Sugi and Dewi, Utami. (2015). Collaborative Governance dalam Pembudayaan Etika Berlalu-Lintas Pelajar SMA di Kota Yogyakarta. E-Journal of Universitas Negeri Yogyakarta

[17] Rahmawati, A. (2016). Kolaborasi Antar Daerah Pawonsari dalam Penyelesaian Konflik Antar Nelayandi Perairan Pacitan, Wonogiri dan Gunung Kidul. Universitas Sebelas Maret.

[18] Sudarmo. (2011). Isu Isu Administrasi Publik dalam Perspektif Governance. Smart Media.

[19] Sufianty, E. (2014). Kepemimpinan dan Perencanaan Kolaboratif pada Masyarakat Non Kolaboratif (Leadership and Collaborative Planning in Non-Collaborative Community). Journal of Regional and City Planning, 25(1), 78-96. http://journals.itb.ac.id/index.php/jpwk/article/view/1280/814

[20] Sugiyono. (2012). Metode Penelitian Kualitatif. Alfabeta.

[21] Tilano, Fawwas Adi and Suwitri, Sri. (2019). Collaborative Governance In An Effort To Traffic And Road Transportation Safety In Semarang City. e-Journal of Universitas Diponegoro

[22] Thomson, A. M. and J. L. P. (2006). Collaboration Processes: Inside the Black Box. Public Administration Review.

[23] Undang-Undang Republik Indonesia Nomor 22 Tahun 2009 Tentang Lalu Lintas Dan Angkutan Jalan (Patent No. 22). (2009). 